\title{
Weaknesses Of The Implementation Of The State Administrative Court Verdicts: A Case Study In Indonesia
}

\author{
Francisca Romana Harjiyatni ${ }^{1}$, Farid Ario Yulianto ${ }^{2}$ \\ \{fr_romana_harjiyatni@janabadra.ac.id ${ }^{1}$, fsaeba@gmail.com² ${ }^{2}$ \} \\ Janabadra University, Yogyakarta, Indonesia
}

\begin{abstract}
Fair legal protection is hampered by the Administrative Court Verdicts that cannot be enforced in the event that the government officials as the defendants are not willing to voluntarily carry out the Administrative Court Verdicts. The presence of Law No. 30 of 2014 concerning the Government Administration does not provide a way out to overcome this obstacle. The Government Administration Law gives the authority to carry out the Administrative Court Verdicts entirely to the executives/government. The Administrative Court is not authorized to carry out the Administrative Court Verdicts. The Government Administration Law further weakens the functions of the Administrative Court, because the Administrative Court does not have the authority to carry out the verdicts, and in fact the authority is fully delegated to the executives/government. Optimal legal protection for the people is very dependent on the legal awareness of the officials to comply with the Administrative Court Verdicts.
\end{abstract}

Keywords: Verdict, Administrative Court, Government Administration.

\section{Introduction}

Administrative Court has a weakness in providing legal protection for the justice seekers, namely that the Administrative Court Verdicts cannot be enforced in the event that the government officials as the defendants are not willing to carry out the Administrative Court Verdicts. Based on Law No. 5 of 1986 in conjunction with Law No. 9 of 2004 as well as Law No. 51 of 2009, the implementation of the Administrative Court Verdicts was more directed to whether or not the officials voluntarily carry out the verdicts. Even though Law No. 9 of 2004 and Law No. 51 of 2009 regulate the provisions of dwangsom, namely the imposition of a number of forced money for the government officials as the defendants who are not willing to voluntarily carry out the Administrative Court Verdicts, but this provision has not yet been implemented, because there are no implementing regulations on forced money yet.

Compliance of the Government Officials to carry out the verdicts either through forced efforts, or even voluntarily, is still apprehensive and does not reflect the compliance of the Government Officials to carry out the court verdicts properly.[1] In practice, not all Administrative Court Verdicts are carried out by the Government Officials. [2] According to Supandi, "The existence of Administrative Court Verdicts that are not obeyed by the Government Officials is one of the things that causes people to be still pessimistic about the existence of Administrative Courts". [3]

Disobedience of the Government Officials to carry out the Administrative Court Verdicts results in the Administrative Court being less functional to be able to provide maximum legal 
protection for the justice seekers. If the Government Officials do not carry out the Administrative Court Verdicts, then the plaintiff or justice seeker will only win on paper and cannot enjoy their victory so that the sacrifice that they have made to sue to the Administrative Court will be in vain. [4]

In an effort to realize good governance, Law No. 30 of 2014 concerning the Government Administration was established. The Government Administration Law regulates the provisions that are related to the Administrative Procedure Law, so that there are changes in the Administrative Procedure Law as stipulated in the Government Administration Law, including those that are related to the implementation of the Administrative Court Verdicts. This paper will describe the weakness of the implementation of the State Administrative Court Verdicts in Indonesia.

\section{The Weaknesses Of The Implementation Of The State Administrative Court Verdicts In Indonesia}

Since it was formed until now, the Administrative Court has weaknesses, so that it cannot carry out its functions to the fullest in providing protection to the people. In this regard, Stewart Fenwick [5] said,

The Court has steadily declined in prominence, and has not found a voice in postreform Indonesia. In many respects the jurisdiction is largely invisible, and is notable for its comparatively light caseload, poor enforcement powers, and an apparent inability to generate significant jurisprudence.

Furthermore, Stewart Fenwick said,"While the draft Law on Government Administration sets out new standards for administrative decision-making, it does not alter the framework for review mechanisms in any fundamental way". After the Government Administration Law was established, it did not undergo many changes in the regulations regarding the way to test the decisions of the government officials, which also include the matters regarding the forced power of the implementation of Administrative Court Verdicts. The implementation of the verdicts still has low forced power.

The Government Administration Law provides an expansion of the absolute competence of the Administrative Court. Thus, this matter brings implications on the changes in the administrative court procedural law to adjust to the changes that have been regulated in the Government Administration Law. These changes include not only the absolute competence that is widely increasing, but these changes should be followed by an increase in forced power towards the implementation of the Administrative Courts Verdicts.

Until present time, there has been no new Administrative Court Law to adjust to the Government Administration Law. However, the concept or draft of the new Administrative Court Law to adjust to the Government Administration Law has been compiled but has been suspended in the hearing in the House of Representatives, so that the new Administrative Court Law has not been stipulated until now. Regarding the implementation of Administrative Court Verdicts, the concept or draft of the Law in Article 134 states as follows:

(1) The court clerk on the order of the head of the court sends a copy of the court verdicts that have permanent legal force to the parties and the minister.

(2) The defendant is obliged to carry out the court verdicts that have permanent legal force.

(3) Supervision of the implementation of the verdicts is conducted by the President as the highest head of the government 
(4) The supervision referred to in verse (3) can be delegated to the minister.

(5) The minister referred to in verse (4) is obliged to report the implementation of the verdicts that have legal force to the Chair of the Supreme Court of the Republic of Indonesia with a copy to the Chair of the first level court.

(6) The head of the court coordinates with the minister on the implementation of the verdicts that have permanent legal force.

(7) The Chair of the Court reports the results of the execution of the verdicts that have permanent legal force to the Supreme Court at the end of each year.

Based on the provisions in the draft of the Law, it shows that the implementation of the Administrative Court Verdicts is given entirely to the executives or the government as the defendant to carry it out. The Administrative Court as the judicial institution is not given the authority to force so that the Administrative Court Verdicts will be carried out by the government officials as the defendants. This is due to the issue of the verdicts implementation by the Government Administration Law that gives the full authority to the government/executives on whether or not they will carry it out.

Article 7 verse (2) letters $\mathrm{k}$ and 1 of the Government Administration Law states that the government officials have the following obligations:

a. Carry out the verdicts and/or legitimate actions and verdicts that have been declared invalid or canceled by the court, the relevant officials, or superior officer;

b. Comply with the court verdicts that have permanent legal force.

Furthermore, Article 72 verse (2) of the Government Administration Law states that,

Governments and/or Government Officials are obliged to carry out the verdicts and/or legitimate actions and verdicts that have been declared invalid or canceled by the Court or the relevant officials or concerned superior officer.

These provisions indicate that the government officials have an obligation to comply with the court verdicts. Obligations are legal provisions that must be carried out by the government officials in carrying out their duties and authorities. In the event that the obligation is not implemented, sanctions that have been regulated in the Government Administration Law will be imposed. Based on Article 80 verse (2) of the Government Administration Law, the Government Officials who do not carry out the Administrative Court Verdicts are subject to moderate administrative sanctions.

Article 81 verse (2) of the Government Administration Law states that the moderate administrative sanctions include:

a. Forced money payment and/or compensation;

b. Temporary termination while obtaining office rights; or

c. Temporary termination without obtaining office rights

These provisions indicate that the officials who do not carry out the Administrative Court Verdicts are subject to sanctions including payment of forced money or known as $d$ wangsom, but the authority to implement dwangsom is given to the executives and not to the judiciary (administrative court institution). This is more clearly stated in Article 82 of the Government Administration Law as follows:

(1) The imposition of sanctions as referred to in Article 81 is carried out by:

a. The supervisor of the Decision Officer;

b. The regional head if the verdicts are determined by the regional officials;

c. The minister/head of the institution if the verdicts are determined by an official in the environment; and 
d. The president if the verdicts are determined by the ministers/leaders of the institution.

(2) The imposition of sanctions as referred to in Article 81 is carried out by:

a. The governor if the verdicts are determined by the regent/mayor; and

b. The minister who organizes the domestic government affairs if the verdicts are determined by the governor.

The description above shows that the Government Administration Law requires that the authority to carry out the Administrative Court Verdicts is given entirely to the executives. The Administrative Court as a judicial institution has no authority at all in the implementation of the Administrative Court Verdicts, which is a very ironic thing. On one hand, the Government Administration Law provides very broad absolute competence to the Administrative Court, but on the other hand the Administrative Court does not have the authority to execute the Administrative Court Verdicts. It appears that the initiators of the Government Administration Law are more rigid in applying the theory of separation of powers. The Administrative Court is only placed as the supervisory institution, and the Administrative Court Verdicts are only a kind of recommendations. The follow-up of the recommendations is left entirely to the executives, which is not much different from other supervisory institutions. In this case, the Administrative Court has a function as a supervisory institution that is no different from other supervisory institutions. The function as a judicial institution is less apparent in the Administrative Court itself, because the characteristic of a judicial institution is to have full authority to solve the cases that are tried there until the court verdicts can actually be carried out.

In the event that the provisions governing the implementation of the verdicts are given entirely to volunteerism of the executives or the government officials; it will raise questions in the event that the defendant is an official in the legislative environment, judicial environment and other state administrator institutions. In accordance with the provisions in Article 87 of the Government Administration Law, the Government Official Verdicts include the verdicts made by the officials in the legislative, executive, judicial environments and other state administrator institutions. Thus, the officials in the legislative, executive, and judicial environments as well as other state administrator institutions can be sued and become the defendants in the Administrative Court. If in a dispute there are officials in the legislative, executive, and judicial environments as well as other state administrator institutions who are sued in which the plaintiff win, questions on how to carry out the verdicts of the Administrative Court will arise.

Article 134 in the draft of the Law creates something that is unreasonable, if the defendant is an official in the legislative environment or other state administrator institutions, it is very unlikely that the supervision of the implementation of the verdicts is conducted by the President as the highest government head or delegated to the Minister.

In the event that the defendant is a government official, then the supervision of the implementation of the court verdicts is given to the President. Therefore, in the case of the defendant is an official in the legislative and judicial environment or other state administrator institutions, the supervision should be left to the highest leader of each institution. This causes the forced power of the implementation of the Administrative Court Verdicts to be very dependent on each institution. Such a model would make the Administrative Court's authority broader in resolving disputes. On the other hand, the execution of the Administrative Courts Verdicts became weaker. The greater the authority, the stronger the State Administrative Court institution should be, especially in carrying out its functions in resolving disputes to the completion of the verdicts of the Administrative Court. The fact that the Administrative Court 
has greater absolute authority but does not have the authority to execute its decisions has made the Administrative Court institutions become weaker as the institutions that should be providing justice for the people.

There are many theories of separation of powers which define that judicial power, including the Administrative Court institutions, only has the authority to oversee or control the government, but does not have the authority over the execution of the Administrative Court Verdicts, and considers that the authority to execute the verdicts is in the hands of the executives. In the case of the Administrative Court is given the authority to be able to execute the Administrative Court Verdicts, it is considered as a form of judicial intervention against the executives, and this is considered to be in contrast to the theory of separation of powers.

In fact, the weak authority of the Administrative Court in carrying out (executing) the Administrative Court Verdicts causes the justice seekers to not obtain fair protection when the government officials as the defendants are not willing to voluntarily carry out the Administrative Court Verdicts. This is in contrast to the purpose of the theory of separation of powers, namely that with the separation of powers, it is hoped that the people will get legal protection from the abuse of power of the authorities. This is in accordance with what was stated by Phineas M Mojapelo as follows, "The main objective of the doctrine is to prevent the abuse of power within different spheres of government" [6], which means that the main purpose of the theory of separation of powers is to prevent the occurrence of the abuse of power of the government. On the contrary, the inability of the Administrative Court Verdicts to be carried out in the event that the government officials are not willing to voluntarily carry out the verdicts, the people seeking justice do not get legal protection from the abuse of power of the authorities. following:

Related to the theory of separation of powers, A W Bradley and K D Ewing stated the

As the contrast between the United States and France shows, the doctrine of separation of powers has a variety of meanings. The concept of 'separation' may mean at least three different things:

(a) that the same persons should not form part of more than one of the three organs of government, for example, that ministers should not sit in Parliament;

(b) that one organ of government should not control or interfere with the work of another, for example, that the executive should not interfere in judicial decisions;

(c) that one organ of government should not exercise the functions of another, for example, that ministers should not have legislative powers.

In considering these aspects of separation, it needs to be remembered that complete separation of powers is possible neither in theory nor in practice. [7]

One of the concepts of separation of powers means that one organ of government is not permitted to interfere with other organs of government, for example the executive interferes the judiciary or vice versa. Such definition does not mean that the Administrative Court cannot be given the authority to execute the verdicts of the Administrative Court if the government officials are not willing to voluntarily carry out the verdicts of the Administrative Court. In the case of the Administrative Court is given the authority to carry out their verdicts by Law, then the authority is not a form of judicial intervention against the executives. In the case that the Law does not give authority to the Administrative Court to execute the Administrative Court Verdicts, then if the Administrative Court forces the government officials to carry out the verdicts, that is a form of judicial intervention against the executives. Furthermore, A W Bradley and K D Ewing said that, 
The proper constitutional relationship of the executive with the courts is that the courts will respect all acts of the executive within its lawful province, and that the executive will respect all decisions of the courts as to what its lawful province is.

In relation with the relationship between the executives and the judiciary in the doctrine of the separation of powers, the court will respect all executive actions in accordance with their legal authority, and the executives will respect all decisions from the court in accordance with their authority. The basis of all this is authority, in the case that the Administrative Court is given the authority to execute the Administrative Court Verdicts, then the Administrative Court's attempt to force the government officials to carry out the Administrative Court Verdicts is not a form of judicial intervention against the executive and does not contradict the theory or teachings of separation of powers.

\section{Conclusion}

Since it was promulgated and changed twice, Law No. 5 of 1986 in conjunction with Law No. 9 of 2004 and Law No. 51 of 2009 did not experience a significant change in the implementation of the Administrative Court Verdicts. The implementation of the Administrative Court Verdicts has a low force power, namely that the implementation of the Administrative Court Verdicts is given to the volunteerism of the Government Officials to carry out the Administrative Court verdicts. The existence of the Government Administration Law actually weakens the function of the Administrative Court in the implementation of the Administrative Court Verdicts. Based on the Government Administration Law, the authority to carry out the Administrative Court Verdicts is more fully delegated to the government officials.

The culture of compliance towards the Court Verdicts by the Government Officials in Indonesia is still low. Therefore, arrangements that are related to the implementation of the Administrative Court Verdicts based on the Government Administration Law certainly do not provide legal protection for the people. It is necessary to revise the Government Administration Law and the Administrative Court Law which contain new regulations that will give strong authority to the Administrative Court in carrying out the verdicts.

\section{References}

[1] Enrico Simanjuntak, E.: Prospek Ombudsman Republik Indonesia Dalam Rangka Memperkuat Pelaksanaan Eksekusi Putusan Peradilan Tata Usaha Negara. Jurnal Hukum dan Peradilan, Volume 3, Number 2 July 2014.

[2] Untoro, "Self-Rescpect dan Kesadaran Hukum Pejabat Tata Usaha Negara Menuju Keadilan", Pandecta, Volume 13 Number 1 June 2018.

[3] Supandi. 2011. State Administrative Court Law (Compliance with Government Officials in Complying with the Decision of the State Administrative Court). Medan : Pustaka Bangsa Press.

[4] Francisca Romana Harjiyatni dan Sunarya Raharja, "Fungsi Peradilan Tata Usaha Negara Dalam Menyelesaikan Sengketa Lingkungan (Studi Gugatan Organisasi Lingkungan Hidup)”, Mimbar Hukum, Jurnal Berkala Fakultas Hukum Universitas Gadjah Mada, Volume 26, Nomor 2, Juni 2014.

[5] Stewart Fenwick. Administrative Law And Judicial Review In Indonesia-The Search For Accountability. Tom Ginsburg and Albert H. Y. Chen. Administrative Law and Governance in Asia Comparative perspectives. Oxon : Routledge.

[6] Phineas M Mojapelo. The doctrine of separation of powers (a South African perspective). Paper delivered at the Middle Temple South Africa Conference, September 2012.

[7] A W Bradley dan K D Ewing. 2007. Constitutional And Administrative Law. Fourteenth Edition. Essex : Pearson Education Limited. 